\section{Богдан КРИВОЛАПОВ}

\section{Поняття реституції та повернення культурних цінностей у сучасній доктрині міжнародного права}

\begin{abstract}
Стаття присвячена аналізу співвідношення понять «реституції» та «повернення» культурних цінностей в сучасних юридичних доктринах. Автор досліджує різни підходи та концепції щодо визначення цих термінів. У статті також розглядається соціально-культурне значення реституції культурних цінностей.

Ключові слова: реституція, культурні цінності, повернення, культурна спадщина.

The article is devoted to the analysis of the relation between the concepts of «restitution» and «return» of cultural values in modern legal doctrines. The author examines different approaches and concepts for the definition of these terms. The social and cultural importance of cultural values restitution is covered by this article
\end{abstract}

Keywords: restitution, cultural values, returning, cultural heritage.

\begin{abstract}
Постановка проблеми. Дослідження питань, пов' язаних з реституцією культурних цінностей є дуже актуальними сьогодні для України, оскільки незважаючи на досить активну позицію нашої держави щодо повернення цінних артефактів, які були незаконно вивезена під час другої Світової війни і в більш ранні періоди, багато ще залишилося невирішених питань і багато цінних вітчизняних артефактів ще знаходитися за кордоном. Крім того, резонансна історія, пов'язана 3 поверненням «скіфського золота», незаконна передача картин з Маріупольського художнього музею імені Куїнджі в Сімферопольський художній музей та деякі інші факти незаконного вивозу культурних цінностей свідчать про те, що реституційні механізми в Україні потребують подальшого удосконалення.
\end{abstract}

Аналіз основних досліджень і публікацій. Теоретичним та методологічним підгрунтям даної статті являються здобутки вітчизняних та зарубіжних вчених: В .Акуленка, М. Богуславського, К. Бусол, Н. Касатенка, Е. Короля, О.О. Підопригори та ін.

Метою даного дослідження є встановлення особливостей механізму реституції культурних цінностей, провести порівняльний аналіз термінів «реституції» та «повернення» культурних цінностей в сучасних наукових доктринах.

Виклад основного матеріалу. Відомий український мистецтвознавець, Голова Національної комісії $з$ питань повернення в Україну культурних цінностей при Кабінеті Міністрів України, академік О.К. Федорук писав: «Сьогодні вже ні в кого не викликає сумніву той факт, що культурні цінності $\epsilon$ важливим елементом формування історичної самосвідомості народів, усвідомлення ними себе як єдиного цілого. Саме культурні цінності виступають як головний чинник підтримки духовного зв' язку поколінь, об'єднують їх в єдиний ланцюг історичного розвитку» $[15,9]$.

Інші автори вказують на те, що культурна спадщина відіграє важливу роль у формуванні історичної пам'яті та національної самосвідомості. Культурна спадщина відображає не тільки минуле, але й активно формує суспільні погляди громадян [6, с.187] .

Ю. Опалько також вказує на те, що культурна спадщина є..., важливим фактором у формуванні української ідентичності [10, с.83 ].

Академік О. Федорук прямо вказує на те, що втрата культурних цінностей, їх відчуження від націй і народів, які їх створили, може мати вкрай негативні наслідки для їх повноцінного розвитку [15, с.9] .

Е. Король стверджує, що відрив культурних цінностей від своїх національних коренів - це тяжкий удар по національній самосвідомості народу, а також по його культурної самобутності [8, с.2] .

УДК.341.9:341.3

https://doi.org/10.36952/uail.2020.3.118-121

๑) Б. М. Криволапов

\section{КРИВОЛАПОВ Богдан}

кандидат юридичних наук, доцент кафедри міжнародного приватного права Інституту міжнародних відносин Київського національного університету імені Тараса Шевченка 
У даному контексті очевидною є роль реституції культурних цінностей, як інструмента, за допомогою якого відновлюється історична пам'ять народів. Завдяки реституції повертаються об'єкти, які становлять культурну спадщину країни, формують морально-етичні орієнтири, встановлюють певні поведінкові правила, які впливають на соціальну структуру суспільства і сприяють на формування світогляду, як окремих етнічних груп, так і цілих народів.

Отже, що таке реституція культурних цінностей?

Поняття реституції було відомо ще стародавньому Римському приватному праву. Сторона, незадоволена судовим рішенням, могла просити у претора restitution in integrum (відновлення в початкове положення). Суть реституції полягала в тому, що вона позбавляла сили факт, що призвів до існуючого стану речей, і відновлювала попередній стан.

Цей засіб захисту застосовувалося не тільки проти судового рішення, але і в ряді інших випадків, коли, на думку претора неможливо було застосувати норми права. Наприклад, договір був укладений неповнолітньою особою, яка в силу своєї недосвідченості переплатила в ціні. Сторона, яка опинилася в невигідному становищі, могла звернутися до претора 3 проханням визнати недійсним такий договір. Претор визнавав такий договір недійсним і повертає сторони до попереднього стану речей.

Слід зазначити, що реституція застосовувалася у чітко визначених випадках: неповноліття однієї зі сторін (minor aetas), обман (dolus), помилка (error), загроза (metus), відсутність (absentia justa). Для застосування реституції потрібні були такі умови: наявність шкоди у потерпілого та термін не більше одного року, після факту виникнення підстав для застосування реституції [11, с. 59].

Дана конструкція, практично без змін, була імплементована в українське цивільне право у статтю ст. 216 Цивільного кодексу України, згідно з якою у разі недійсності правочину кожна із сторін зобов'язана повернути другій стороні у натурі все, що вона одержала на виконання цього правочину, а в разі неможливості такого повернення, зокрема тоді, коли одержане полягає у користуванні майном, виконаній роботі, наданій послузі, - відшкодувати вартість того, що одержано, за цінами, які існували на момент відшкодування [16].

У сучасному міжнародному праві реституція є однією з форм міжнародно-правової відповідальності держав за вчинення протиправних дій. В даному контексті вищевказаний термін означає повернення в натурі майна, яке було неправомірно захоплено і вивезено однією країною 3 території іншої країни під час протистояння або будь-якого іншого збройного конфлікту. Реституція в натурі може бути в формі повернення майна, художніх цінностей, бібліотек, промислового обладнання, транспортних засобів і т.д. Відповідно до сучасної доктрини міжнародного права таке повернення може здійснюватися, коли держава-порушник не тільки відновлює попередній стан речей, але й несе пов' язані з цим витрати (звільнення захоплених територій повернення техніки тощо) [5, с.486].

На думку багатьох теоретиків, основне значення реституції в міжнародному праві полягає в тому, що держава-порушник, має нести відповідальність шляхом усунення або зменшення негативних наслідків такого діяння для відновлення попереднього стану речей [2, с.286].

У разі неможливості здійснити реституцію предметів, що мають індивідуальні ознаки, дозволяється передача предметів такого ж роду (субституція) [12, с.335]. Субституцію ще також називають «компенсаторною реституцією». Тут буде доречним привести визначення Російського федерального закону від 15.04.1998 № 64-Ф3 «Про культурні цінності, що переміщені в Союз РСР у результаті другої Світової війни і знаходяться на території Російської Федерації». Згідно зі ст. 4 цього Закону компенсаторна реституція це вид матеріальної міжнародно-правової відповідальності держави-агресора, яка застосовується у випадках, якщо здійснення відповідальності цієї держави у формі звичайної реституції неможливо, і що полягає в обов'язку даної держави компенсувати заподіяний іншій державі матеріальний збиток шляхом передачі потерпілій державі (або шляхом вилучення потерпілою державою на свою користь) предметів того ж роду, що й пограбовані і незаконно вивезені державою агресором з території потерпілої держави [14].

Проблеми «компенсаторної реституції» в міжнародному праві неодноразово обговорювалися на рівні ООН. У 2001 році в рамках цієї організації був прийнятий Проект статей про відповідальність держав за міжнародно-правові діяння. На базі даного проекту пропонувалося прийняти багатосторонню конвенцію. У Проекті вказані такі форми відшкодування як реституція і сатисфакція [3].

Відповідно до статті 35 Проекту держава, відповідальна за міжнародне-протиправне діяння, зобов' язана відновити становище, яке існувало до вчинення протиправного діяння.

Потерпіла держава має право на компенсацію, якщо понесені нею в результаті правопорушення іншої держави збитки не можуть бути відшкодовані реституцією в натурі, причому ця компенсація охоплює будь-яку понесену потерпілою державою шкоду, яка піддається фінансовому обчисленню та може включати втрачену через правопорушення вигоду у встановленому обсязі й відсотки. 
Також хотілось би звернути увагу на таку на таку форму реституції як ресторація. Ресторація означає таку форму відповідальності, за якої держава-порушник зобов'язується відновити попередній стан певного матеріального об'єкту (відновлення якості питної води, фауни і флори, які постраждали від діяльності держави порушниці) [5, с.485 ].

Як ми вже зазначали, крім реституції, в міжнародному праві передбачена така форми матеріальної відповідальності як сатисфакція.

Сатисфакція - задоволення нематеріальних вимог для відшкодування збитку нанесеного честі і гідності державі.

Також слід зазначити, що ще однією формою матеріальної відповідальності в міжнародному праві $\epsilon$ репарація. Репарація - відшкодування суб'єктом-порушника матеріальної шкоди грошима, товарами, послугами [9, с.145].

Отже, що ж таке реституція культурних цінностей? Професор Акуленко визначає реституцію культурних цінностей в міжнародному праві як особливу форму повернення майна, яке має історичне, культурне, мистецьке й інше значення, що було неправомірно вилучено та вивезено воюючою країною з території держави противника під час збройного конфлікту або іншого міжнародного протиправного діяння. Важливим є висновок професора Акуленка про те, що загальні положення про реституцію в міжнародному праві, повинні бути застосовні до реституції культурних цінностей [2, с. 288-289].

Л.В. Стрільчук вважає, що реституція культурних цінностей в міжнародному праві це особлива форма повернення майна історичного, наукового, художнього та іншого культурного значення, неправомірно вилученого і вивезеного під час збройного конфлікту державою з окупованої нею території іншої держави [13].

На думку інших дослідників, реституція культурних цінностей являє собою відновлення втрачених якостей або положення, а також повернення культурних цінностей, захоплених в результаті військових дій країною-агресором на окупованій території іншої держави [7, с.51].

До реституції культурних цінностей також може бути застосована вже згадана нами «компенсаторна реституція». В даному випадку професор Богуславський зазначає, що мова йде про відшкодування шкоди, заподіяної культурної спадщини, коли повернути сам предмет не є можливим [8, с.234 ].

Останнім часом в літературі проводять розмежування між «реституцією» i «поверненням культурних цінностей». Незважаючи на деяку схожість, ці терміни істотно відрізняються, особливо в питанні статусу культурних цінностей, які є об'єктом домагань.

Професор Акуленко вказує на те, що реституція передбачає законне право держави вимагати повернення незаконного вивезених культурних цінностей, а при «поверненні» культурних цінностей у держави є тільки моральне право вимагати від інших держав повернення культурних цінностей. При цьому держави, які фактично цими об' єктами володіють, формально нічого не порушували [1, с. 169]. Така відмінність веде до певних юридичних наслідків. При «поверненні» культурних цінностей, держава власник може проявити жест доброї волі та повернути культурні цінності, або внаслідок добровільної міждержавної угоди.

Слід зазначити, що в різних нормативних актах термін «повернення культурних цінностей» використовується набагато частіше, ніж реституція. Згідно статті 1 Закону України «Про вивезення, ввезення та повернення культурних цінностей від 21.09.1999 № 1068-XIV, повернення культурних цінностей - сукупність дій, пов'язаних із ввезенням на територію України чи вивезенням із території України на території інших держав культурних цінностей відповідно до позовів і звернень України, інших держав, їх уповноважених органів, рішень судів України або іноземних держав. При цьому сам термін «реституція культурних цінностей» відсутній.

Згідно із ч. 5 статті 1 Директиви Європейської Ради № 93/7 / ЄЕС про повернення культурних об'єктів, незаконно вивезених з території держав-членів від 15 березня 1993 року термін «повернення» означає фізичне повернення культурного об'єкта на територію запитуючої Держави-члена [17].

Незважаючи на відсутність терміну «реституції» у вищевказаних нормативних актах, сам механізм даної форми відповідальності досить-таки детально прописаний. Абсолютно справедливим є твердження професора Акуленка про те, що для чіткого розрізнення даних термінів необхідно подальші наукові напрацювання [1, 169].

Висновки. Підводячи підсумки, хотілося б звернути увагу на той факт, що багато дослідників даної проблеми пов'язували реституцію культурних цінностей в тій чи іншій мірі з будь-яким збройним конфліктом. Цілком очевидно, що використання даного терміну можливо також і при будь-якому іншому незаконному переміщенні культурних цінностей.

Реституцію культурних цінностей можна сформулювати як повернення національних скарбів, що представляють культурну, художню, історичну або археологічну цінність, які були незаконно вивезені $з$ території держави, де вони постійно знаходяться і охороняються національним законодавством. 
Основна відмінність «реституції культурних цінностей від «повернення» полягає в тому, що останнє передбачає можливість повернення культурних цінностей, які знаходяться в іншій державі на законних підставах.

1. Акуленко В.І. Міжнародне право охорони культурних цінностей та його імплементація у внутрішньому праві України / Віктор Іванович Акуленко. - Киев: ЮСТІНІАН, 2013. - 608 с.

2. Акуленко B.I. Терміни як межі міжнародно-правових понять «реституція» і «реституція культурних цінностей» / В.І. Акуленко / / Праці Центру пам'яткознавста. - 2013.- Вип. 24. - С.284-295.

3. Барышев В. Международно-правовые и нравственные аспекты компенсаторной реституции культурных ценностей [Электронный ресурс] / В. Барышев / / Журнал международного права и международных отношений. - 2008. - № 2. - Режим доступу: http:/ / evolutio.info/content/view/1396/215/.

4. Богуславский М.М. Культурные ценности в международном обороте: правовые аспекты: монография / Марк Моисеевич Богуславский. - Москва: Норма ИНФРА-М, 2012. - 416 с.

5. Буткевич В.Г., Мицик В.В., Задорожний О.В. Міжнародне право. Основи теорії: Підручник/ За ред. В.Г.Буткевича. - К.: Либідь, 2002. - 608 с.

6. Денисенко Г., Денисенко О. Меморіальний простір України у формуванні історичної пам'яті / Г.Денисенко, О.Денисенко / / Україна XX століття: культура, ідеологія, політика. - 2016. - Вип. 21. - С. 187-199.

7. Касатенко А.Н. История и теория реституции культурных ценностей / А.Н. Касатенко / / Вестник Таганрогского института управления и экономики. - 2013. - № 1. С.51-55.

8. Король, Э. Проблема реституции культурных ценностей в рамках сотрудничества стран СНГ / Э.Король / / Журнал международного права и международных отношений. - 2008. - № 4. - С. $13-17$.

9. Мицик В.В., Задорожній О.В. Конспект лекиій з основ теорії міжнародного права. - Підручник. / За ред. В.Г.Буткевича. - К.: Либідь, 2001. - 145 с.

10. Опалько Ю.В. Збереження культурно-історичної спадщини в сучасній Україні: проблеми та перспективи / Ю.В.Опалько / / Стратегічні пріоритети. - 2007. - №1 (2). - С. 83-88.

11. Подопригора А.А. Основы римского гражданского права: Учеб. Пособие для студетов юрид. Вузов и факультетов. - 2-е изд., перераб. - К.: Вентури, 1994, - 288 с.

12. Словарь международного права / С.Б.Бацанов, Г.К.Ефимов, В.И.Кузнецов и др. - Москва.: «Международные отношения», 1986. - 432 с.

13. Стрильчук Л.В. Вопросы реституции культурных ценнотей в современных польско-украинских отношениях/ Л.В.Стрильчук // Актуальные проблемы гуманитарных и естественных наук. 2014 - 5-1. [Електронний ресурс]. - Режим доступу: http://publikacia.net/archive/2014/5/1/29

14. Федеральный закон РФ «О культурных ценностях, перемещенных в Союз ССР в результате Второй мировой войны и находящихся на территории Российской Федерации» от 15.04.1998 N 64-Ф3 // Рос. газ. 1998. 21 апр.

15. Федорук О. Культурні цінності - пріоритети держави / / Українські культурні цінності в Росії: Перша спроба повернення, 1917-1919. - К., 1996. - С. 8-14.

16. Цивільний кодекс України [Електронний ресурс]: Сайт Верховної ради України. Режим доступу: http:/ / zakon2.rada.gov.ua/laws/ show/435-15

17. Council Directive 93/7/EEC of 15 March 1993 on the return of cultural objects unlawfully removed from the territory of a Member State [Електронний ресурс]: Сайт доступу до законодавства ЄС. Режим доступу: http:/ / eur-lex.europa.eu/LexUriServ/LexUriServ.do?uri=CELEX:31993L0007:en:HTML

\section{Summary}

The article is devoted to the research of theoretical and practical problems of return and restitution process of cultural values in Ukraine under present-day conditions. The different sources were used for this researching which made possible to investigate some methodological, typological and historiographical questions.

The author compares different approaches and doctrines and gives definitions to such terms as "restitution" and "returning".

The restitution of cultural values is defined as returning of national treasury objects, which have artistic, historical or archaeological values and were illegally exported from the territory of the permanent location state and protected by national legislation.

The main difference between the "restitution" of cultural values and the "returning" is that the last one provides the possibility of cultural values returning by another state which owns them legally. 